\title{
Mastoid Cavity Obliteration with Cartilage Graft; Evaluation of 35 Patients
}

\author{
Kartilaj Greft ile Mastoid Kavite Obliterasyonu; 35 Hastanın \\ Değerlendirilmesi
}

\section{Tayyar KALCIOGLU $\odot$, Ali OZERK $\odot$, Oguz Kadir EGILMEZ $\odot$, Numan KOKTEN $\odot$, Lokman UZUN $\odot$, Yuksel TOPLU $\odot$, Muhammet TEKIN $\odot$}

Ethics Committee Approval: This study approved by the Istanbul Medeniyet University, Goztepe Training and Research Hospital, Clinical Studies Ethic Committee, 1 July 2014, 2014/0090. Conflict of interest: One of the authors of this article is an Editorial Board Member of this journal and was excluded from all evaluation steps. The other authors declare that they have no conflict of interest.

Funding: None.

Informed Consent: Informed consent was taken from the patients.
Cite as: Kalcioglu MT, Ozerk A, Egilmez OK, et al. Mastoid cavity obliteration with cartilage graft; evaluation of 35 patients. Medeniyet Med J. 2019;34:360-7.

\begin{abstract}
Objective: Cartilage is a rigid material that is highly resistant to infection and retraction and is tolerated well by the middle ear. The purpose of this study was to review retrospectively the results of cases of mastoid cavity obliteration with cartilage performed after canal wall down (CWD) mastoidectomy and to discuss the literature.

Method: Of 983 patients who underwent surgery for chronic otitis media between January 2000 and June 2012, 54 patients who underwent CWD mastoidectomy plus mastoid cavity obliteration with cartilage and who were followed up regularly were selected from the database and invited for re-evaluation. All patients who came for a follow up after the invitation were examined and their data were evaluated retrospectively.

Results: Thirty-five of the patients who accepted the invitation were included in the study. All of the patients in the study underwent mastoid cavity obliteration with conchal and/or tragal cartilage grafts. The duration of follow up ranged from 21 to 41 months (average, 27.3 months). Epithelization occurred in all patients with dry cavity, except one who had residual cholesteatoma and underwent revision surgery.

Conclusion: The results of this study indicate that cartilage can be preferred for obliteration of mastoid cavity after CWD mastoidectomy.
\end{abstract}

Keywords: Obliteration, mastoid cavity, mastoidectomy, cartilage

Öz

Amaç: Kartilaj enfeksiyon ve retraksiyona karşı oldukça dirençli ve orta kulak tarafindan iyi tolere edilen sert bir malzemedir. Bu çalışmanın amacı, canal wall down (CWD) mastoidektomi sonrası kartilaj ile mastoid kavite obliterasyon yapılan olguların sonuçlarını geriye dönük olarak gözden geçirmek ve literatürü tartışmaktır.

Yöntem: Ocak 2000 - Haziran 2012 tarihleri arasında kronik otitis media ameliyatı geçirmiş 983 hastadan, CWD mastoidektomi ve mastoid kavite obliterasyonu yapılan ve düzenli aralıklarla takip edilen 54 hasta veri tabanından seçildi ve yeniden değerlendirme için çağrıldı. Tekrar inceleme için gelen tüm hastalar değerlendirilerek verileri retrospektif olarak analiz edildi.

Bulgular: Yeniden değerlendirme için çağırılan hastaların 35'i çalışmaya dahil edildi. Çalışmaya alınan tüm hastalara konkal ve/veya tragal kartilaj greftler ile mastoid kavite obliterasyonu uygulandı. Takip süresi 21 ila 41 ay arasında değişmekte idi (ortalama, 27.3 ay). Rezidüel kolesteatom gelişsen ve revizyon ameliyatı geçirilenlerin haricinde kuru kaviteli tüm hastalarda epitelizasyon görüldü.

Sonuç: Bu çalışmadan elde edilen sonuçlar, CWD mastoidektomi sonrası mastoid kavite obliterasyonu için kartilaj tercih edilebileceğini göstermektedir.

Anahtar kelimeler: Obliterasyon, mastoid kavite, mastoidektomi, kartilaj
Received: 3 September 2019

Accepted: 23 October 2019

Online First: 26 December 2019

Corresponding Author:

O.K. Egilmez

ORCID: 0000-0001-9623-9152

Sakarya University Training and Research Hospital Department of Otorhinolaryngology, Adapazari, Sakarya, Turkey

oguzegilmez@gmail.com

M.T. Kalcioglu ORCID: 0000-0002-6803-5467 N. Kokten ORCID: 0000-0001-6674-9389

L. Uzun

ORCID: 0000-0003-0304-3789

M. Tekin

ORCID: 0000-0002-2807-5499

Istanbul Medeniyet University School of Medicine Goztepe Training and Research Hospital, Department of Otorhinolaryngology, Istanbul, Turkey

A. Ozerk

ORCID: 0000-0002-1236-3971

Y. Toplu

ORCID: 0000-0002-2668-256X Inonu University School of Medicine,

Turgut Ozal Medical Center, Department of Otorhinolaryngology, Malatya, Turkey 


\section{INTRODUCTION}

Surgery is accepted as the mainstay in the management of cholesteatoma. The primary aim in the surgical management of cholesteatoma is creation of a safe, dry ear by eradicating the disease and, if necessary, altering the anatomy to prevent recurrence. This goal has been achieved consistently using canal wall down (CWD) and canal wall up (CWU) techniques. The CWU technique preserves the anatomy of the posterior canal wall, thus avoiding the risk of recurrent cavity infections and eliminating the need for periodic cavity cleaning. The main disadvantage of this technique is a possiblly higher rate of residual disease; therefore, many authors prefer the CWD technique ${ }^{1,2}$. In CWD technique, the posterior canal wall is removed, enhancing exposure of the entire epitympanum and middle ear and helping to ensure complete eradication of the pathology. The recidivism rate can be reduced to as low as $2 \%$ with the CWD technique ${ }^{1}$. However, it can also result in the formation of an unnatural, anatomically and physiologically unsatisfactory mastoid cavity and cavity related problems $\mathbf{s}^{3,4}$.

To eliminate cavity-related problems and improve the stability of the cavity, mastoid obliteration techniques were introduced. Mosher ${ }^{5}$ first introduced the concept of mastoid cavity obliteration using a postauricular soft tissue flap in 1911. Since then, various materials have been used for obliteration, that are divided into two categories as free grafts (biologic and non-biologic); such as cartilage, fat tissue, fascia, hydroxyapatite crystals, and local flaps; such as Palva flap (musculoperiosteal flap), temporoparietal fascia flap, and postauricular myocutaneous flap ${ }^{6-12}$. In some of the applications biologic autogenous flaps and graft materials have been used in combination as musculoperiosteal flap plus bone pate or cartilage plus musculoperiosteal flap ${ }^{12,13}$.

To date, the results of mastoid obliteration with different materials have been reported. In the present study, we described our technique and discussed the mid-term results of patients who had mastoid cavity obliteration with cartilage graft.

\section{MATERIALS and METHODS}

The research protocol used in this study was approved by the Istanbul Medeniyet University, Goztepe Training and Research Hospital, Clinical Studies Ethic Committee, on July 1, 2014 with decision no. 2014/0090. Informed consent was taken from the patients.

The database included data of 983 patients who underwent surgery due to chronic otitis media, performed by the same surgeon between January 2000 and June 2012 . Fifty four of 983 patients who underwent CWD mastoidectomy plus mastoid cavity obliteration with cartilage and who were followed up regularly were selected and evaluated retrospectively. Because of chronic otitis media with cholesteatoma, patients who had undergone CWD mastoidectomy plus cavity obliteration were included in the study and invited to the clinic for re-evaluation. Informed consent was taken from all patients included in the study. All procedures performed in studies involving human participants were in accordance with the ethical standards of the institutional and/ or national research committee and with the 1964 Helsinki declaration and its later amendments or comparable ethical standards.

Presence of preoperative otorrhea or tympanic membrane perforation; perioperative findings such as presence of cholesteatoma, granulation, or polypoid tissue in the middle ear; surgical techniques performed; and number of previous surgeries were noted. All patients who came to the clinic for follow up control after the invitation were examined by otomicroscope and $0^{\circ}$ and $45^{\circ}$ endoscopes. Diffusion magnetic resonance imaging (MRI) was performed if needed. Residual or recurrent cholesteatoma, retraction pocket, otorrhea, or auricular deformities were noted. 


\section{Surgical technique}

After conchal/tragal cartilage and temporalis fascia were harvested, CWD mastoidectomy was performed when the presence of the extensive cholesteatoma could not be completely cleaned by CWU technique. Sodium 2-mercaptoethanesulfonate (MESNA, Ureomitexan ${ }^{\circledR}$, Baxter oncology, Germany) which is a synthetic sulfur compound that produces mucolysis by splitting the disulfide bonds of the mucous polypeptides, was used for some cases to remove cholesteatoma matrix totally from the operative field. MESNA can disrupt the disulfide bonds of keratin which is the main component of cholesteatoma matrix and can facilitate the dissection of the cholesteatoma matrix totally. During the surgery; MESNA was diluted with saline (20\% MESNA and $80 \%$ saline) and applied after cholesteatoma debris was aspirated but still a remnant of cholesteatoma matrix was left behind. The disulfide bonds of the cholesteatoma matrix are considered to be disrupted by MESNA approximately 5 minutes after application. All infected air cells were drilled and the cholesteatoma matrix was tried to be removed as a whole (Figure 1). Hemostasis was achieved and small pieces were prepared from the whole big cartilage harvested from the conchal or tra-

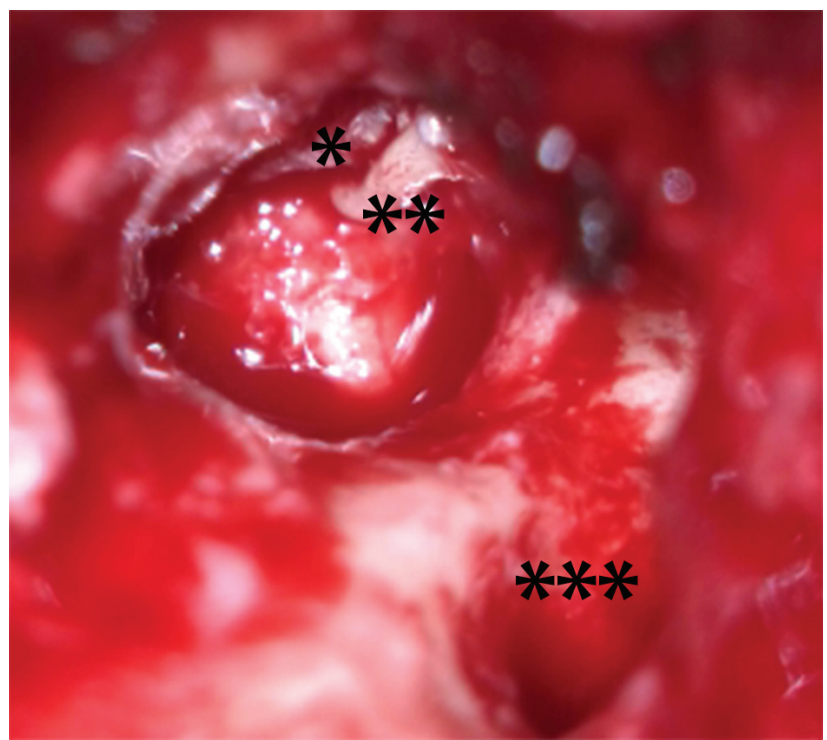

Figure 1. This figure shows a large mastoidectomy cavity; *indicates tympanic membrane remnant, "*manibrium mallei, and ${ }^{* * *}$ mastoidectomy cavity. gal cartilages. All mastoid cavity was filled with full-thickness cartilage plates for obliteration. The temporal muscle fascia was used in all cases to cover cartilages (Figure 2, 3). The ear canal skin was replaced and covered the cartilages partially. The external auditory canal was packed with gelfoam and antibiotic ointment and all incised layers were closed All patients were followed up up to 41 months.

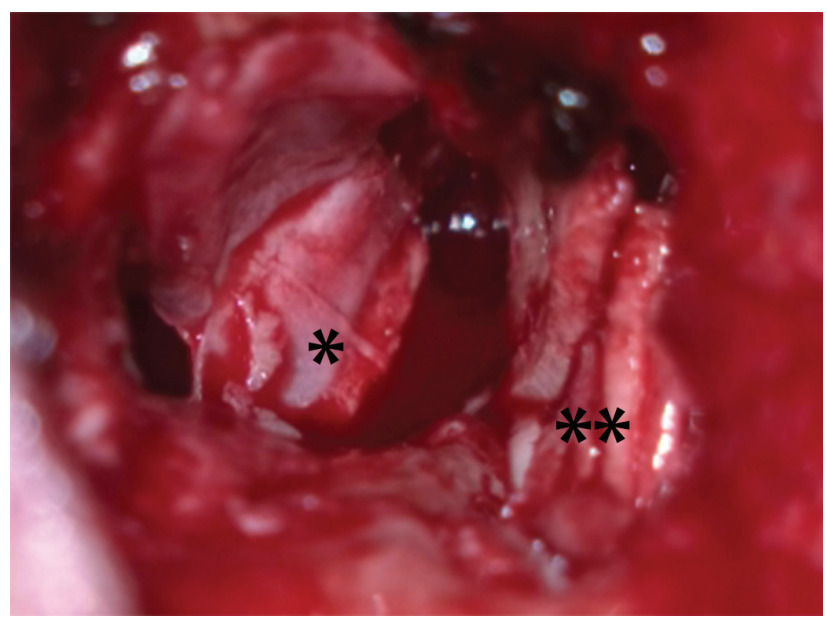

Figure 2. Cartilage island graft for tympanoplasty is shown by ${ }^{*}$, and cavity obliterated with cartilage is shown by**.

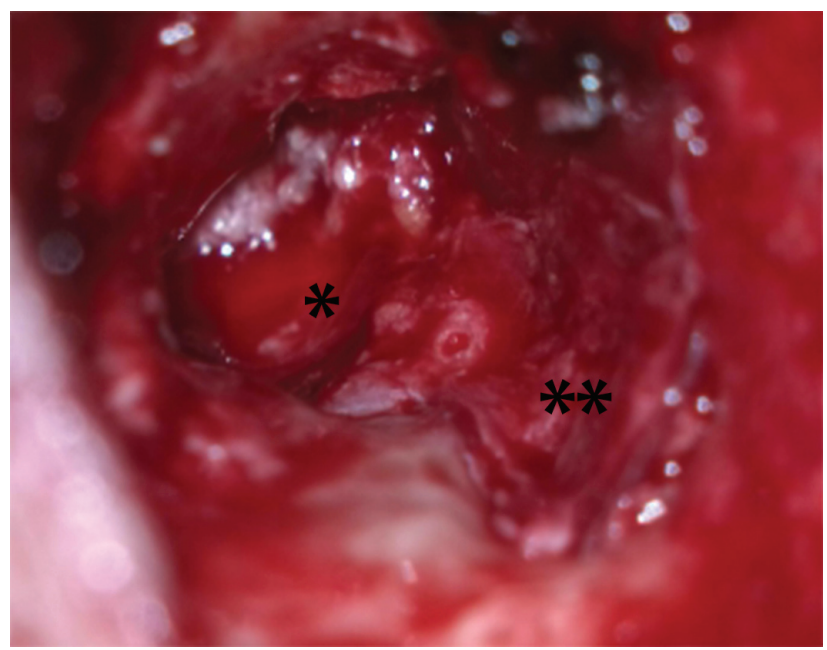

Figure 3. In this figure, *indicates cartilage island graft and **indicates temporal muscle fascia overlying cartilages.

The data obtained were presented as means and percentages in the result section. 


\section{RESULTS}

Thirty-seven of the 54 patients $(68,5 \%)$ who underwent CWD mastoidectomy plus cartilage cavity obliteration and followed up between October 2010 and March 2014 were enrolled in the study. Two of the 37 patients were excluded due to a lack of preoperative findings for comparison; thus, 35 patients were included in the study. The demographic and preoperative pathologic findings were given in Table 1.

Table 1. Demographic findings of the patients.

\begin{tabular}{ll}
\hline Total patients & 35 \\
Mean age $(\mathrm{yr})$ & $33.9 \mathrm{yr}($ range, 11-57 yr) \\
Sex (F/M) & $19(54 \%) / 16(46 \%)$ \\
Side (L/R) & $14(40 \%) / 21(60 \%)$ \\
$\begin{array}{l}\text { Avarage postoperative } \\
\text { follow-up (mo) }\end{array}$ & $27,3 \mathrm{mo}$ (range, 21-41 mo) \\
$\begin{array}{l}\text { Pathology; } \\
\quad \text { Preoperative ear discharge }\end{array}$ & 10 \\
$\begin{array}{l}\text { Tympanic membrane } \\
\text { perforation }\end{array}$ & 19 \\
$\begin{array}{l}\text { Retraction without perforation } \\
\text { Cholesteatoma }\end{array}$ & 16 \\
& 35 \\
\hline
\end{tabular}

Normal hearing acuity was restored with incudostapedial rebridging with bone cement in 3 $(8.6 \%)$, interposition of incus between the stapes suprastructure and the malleus in $10(28.6 \%)$ or between the stapes footplate and the malleus 5 (14.3\%), partial ossicular replacement prosthesis

Table 2. Type of surgical modalities for hearing restoration during the first and second look surgeries.

\begin{tabular}{ll}
\hline Surgical Modality for Hearing Restoration & \# of Patients \\
$\begin{array}{l}\text { Incudostapedial rebridging with bone cement } \\
\text { II between the stapes suprastructure and the }\end{array}$ & $10(28.6 \%)$ \\
malleus & $5(14.3 \%)$ \\
II between the stapes footplate and the & \\
malleus & $7(20 \%)$ \\
PORP & $4(11.4 \%)$ \\
TORP & \\
Surgical Modality of Hearing Restoration \\
During the Second Look Surgery \\
Incus interposition between the stapes \\
footplate and the malleus \\
PORP \\
TORP
\end{tabular}

II: Incus interposition; PORP: Partial ossicular replacement prothesis; TORP: Total ossicular replacement prothesis; \#: Number
(PORP) in 7 (20\%), and total ossicular replacement prosthesis (TORP) in 4 (11.4\%) patients. Restoration of hearing during the second-look surgery was planned for six (17.1\%) patients who had extensive mastoid disease in whom recurrence of cholesteatoma was suspected. The secondlook surgeries were performed 9-12 months after the first operations, and cholesteatoma was not observed in any of the six patients. The patients $(5.7 \%)$ underwent incus interposition between the stapes footplate and the malleus ( $n=2 ; 5.7 \%)$, PORP $(n=2)$, or TORP $(n=2)$ (Table 2$)$.

MESNA was used in 19 of 35 patients (54\%) during surgery. Residual cholesteatoma was observed in only one of 16 patients in the non-MESNA group after otomicroscopic and radiologic evaluations, and revision surgery was performed. Any postoperative residual cholesteatoma was not observed after surgery in the other 15 patients in the nonMESNA group or in the patients in the MESNA group based on otomicroscopic, endoscopic, radiologic, and/or surgical evaluations performed during second- look surgeries.

Epithelization occurred in all patients with dry cavity except one (Figure 4). Retraction in the obliter-

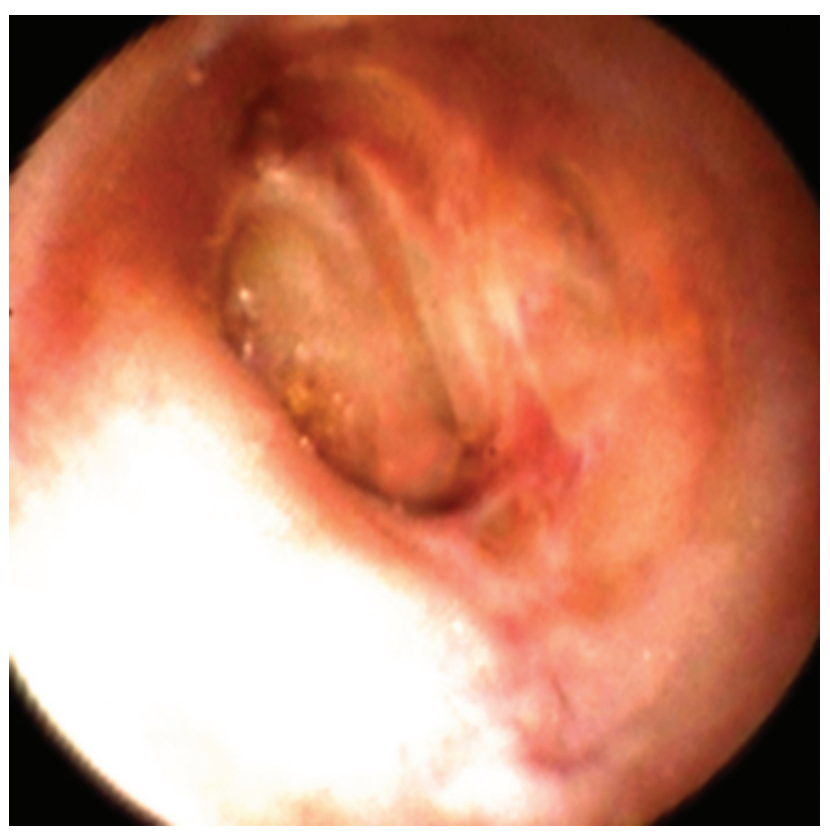

Figure 4. Obliterated cavity three years after surgery. 
ated mastoid area was only observed in two patients $(5.7 \%)$, who had postoperative retraction in the anterior attic space. In one of those patients, the retraction was not deep and a small cartilage graft was placed in the anterior attic space with a transcanal operation; and a T-type ventilation tube was used in the second patient. One of the patients had residual cholesteatoma and required another operation. There were no indication of postoperative graft resorption or deterioration of the external auditory canal contour.

\section{DISCUSSION}

The primary goal of cholesteatoma surgery is eradicating the disease and maintaining a safe and dry ear. Although it is important, restoration of the hearing is a secondary goal ${ }^{14}$. In the CWU technique, the posterior canal wall remains intact and the anatomy is maintained, but postoperative residual and recurrent cholesteatoma rates are higher compared with the CWD technique, especially in children ${ }^{15}$. Due to the lower recidivism and recurrence rates, the CWD technique has been considered the preferred surgical technique for cholesteatoma surgery, ${ }^{1,9}$. Disadvantages of this technique are chronic otorrhea, dizziness and vertigo due to direct caloric stimulation, accumulation of debris requiring regular cleaning of the cavity, cosmetic problems due to large meatoplasty, and difficulties in placing and using hearing aids ${ }^{3,4,16}$. Cavity obliteration is an option for minimizing these types of cavity problems. In this study, the benefits of mastoid cavity obliteration with cartilage performed after CWD mastoidectomy were wanted to be emphasized so audiological results of the patients were not focused, evaluated and analyzed. Although hearing acuity was not evaluated, hearing enhancing surgical methods were applied to the patients; such as incudostapedial re-bridging with bone cement, interposition of incus between the stapes suprastructure and the malleus, or between the stapes footplate and the malleus, PORP, and TORP.
The concept of mastoid cavity obliteration was first introduced by Mosher ${ }^{5}$ in 1911 and is performed for various indications. The most reasonable indication for cavity obliteration is CWD mastoidectomy for chronic otitis media. The other indications are chronic otorrhea or non-healing mastoid cavity, cerebrospinal fluid leak, extensive temporal bone trauma, temporal bone resection for malignancy, and cochlear implantation in patients with chronic otitis media ${ }^{17}$. Persistent active diseases such as cholesteatoma, active infection, or malignancy are relative contraindications for mastoid obliteration, with the exception of extensive malignancy requiring radiation therapy following subtotal resection ${ }^{17}$.

Different types of materials have been used for cavity obliteration which can be categorized as biologic and non-biologic free grafts and local flaps. The most commonly used materials are cortical bone, bone pate, cartilage, fat tissue, hydroxyapatite crystals, bioactive glass ceramics, and Palva musculoperiosteal flap. Each material has its advantages and disadvantages. Biological materials resist to infection very strongly, but they have the disadvantages of resorption, curvature, atrophy, difficulty in fashioning, and donor site morbidity ${ }^{16}$. Gantz et al. ${ }^{14}$ reported wound infection as the main cause of complications after cavity obliteration with biologic materials, and storing the materials in antibiotic solutions before using might help solve this problem. Lee et al. ${ }^{18}$ supported this opinion in a study in which cortical bone pate was used for obliteration of the mastoid cavity.

The absence of donor site morbidity and the absence of resorption are considered to be advantages of non-biologic alloplastic materials such as hydroxyapatite crystals. On the other hand, some complications, such as infection, extrusion, recurrence of discharge, granulation tissue formation, defect in the re-epithelization of the external canal, post-auricular fistula, and canal dehiscence might be seen when synthetic materials are used ${ }^{19}$. Foreign body reactions with silicone, dehiscence 
problems with Proplast, infection and encephalopathy with ionomer cement, and absorption and lysis with Ceravital have been also reported ${ }^{20-23}$.

Autologous cartilage has some advantages, such as ready availability in the surgery field, ease of shaping, and no extra $\operatorname{cost}^{24}$. Cartilage is resistant to negative middle ear pressure, increases stability, and minimizes postoperative adhesions ${ }^{25}$. It has a low metabolic rate and receive nutrients by diffusion ${ }^{24,25}$. The perichondrium has an important role in the nourishment and viability of cartilage; therefore, it is recommended that at least one side of the perichondrium be left intact, for long-term viability ${ }^{24}$. In our cases, we preserved at least one side of the perichondrium, as recommended.

Obliteration of the mastoid cavity after CWD also reduces the frequency of dizziness and vertigo due to caloric stimulation ${ }^{25}$, which results in improved quality of life. Using the Glasgow Benefit Inventory quality of life survey, Dornhoffer et al., and Kurien et al. ${ }^{26,27}$ reported significantly improved quality of life in patients who underwent mastoid obliteration after mastoidectomy. None of the patients in our study experienced dizziness or vertigo after surgery.

In addition, only one of our patients had residual or recurrent cholesteatoma postoperatively. The patient with residual cholesteatoma underwent revision surgery and was treated without complication. Mastoid cavity obliterations can hide problems during follow-up, especially regarding residual cholesteatoma, as the materials used for obliteration might act as a barrier to visualizing the residual cholesteatoma. Some reports have suggested that diffusion-weighted MRI helps to diagnose and identify postoperative residual or recurrent disease during follow up ${ }^{28}$. Improvements in MRI techniques have led to a more definitive diagnosis of cholesteatoma using diffusion-weighted imaging ${ }^{29}$. This provides great ease of postoperative follow-up of patients for recurrent or residual cholesteatoma. In this study, we performed dif- fusion-weighted MRI as needed after the otoendoscopic evaluations or if the patient had some vestibular or otologic problems such as vertigo, otalgia, or otorrhea. Another important point is that delayed residual or recurrent cholesteatoma can occur in mastoid cavity obliterated cases; as such, long-term follow up is recommended ${ }^{30,31}$. In the current study, the follow up period ranged from 21 to 41 months (average, 27.3 months). This period might be long enough, but a longer follow up period might be better.

In the current study, two patients had postoperative retraction in the anterior attic space. One of these patients was treated with placement of a small cartilage graft with transcanal operation, and the other patient was treated with a T-type ventilation tube. Negative pressure in the middle ear and mastoid region is instrumental in the formation of tympanic membrane retraction. The primary determinant of middle ear pressure is the rate of gas absorption across the mastoid mucosa, and it is proposed that increased nitrogen absorption from diseased mucosa might lead to an increase in negative middle ear pressure ${ }^{32}$. Inflammatory conditions that increase the vascularity of the epithelium increase negative pressure inside the middle ear and lead to absorption higher amounts of nitrogen. Therefore, during surgery, exenteration of the mastoid epithelium might facilitate rehabilitation of a poorly aerated ear ${ }^{14}$. In addition, to prevent the formation of retraction, attention should be paid to the attic and posterior epitympanum region that should be obliterated during surgery in case of need. In a study published in 2005 by Lee et al. ${ }^{19}$, mastoid and epitympanic obliterations were performed in patients with scutum defect and dysfunction of the Eustachian tube to prevent retraction pockets.

MESNA is a disulfide bond-breaking, synthetic, chemical agent that produces mucolysis by splitting the disulfide bonds of the mucous polypeptides. It has been reported that application of MESNA dissects tissue layers during cholestea- 
toma or atelectatic ear surgeries by breaking the disulfide bonds of the matrix. MESNA has also been reported to increase success rates of surgery and decrease rates of residual cholesteatoma formation $^{33,34}$. In this study, there was no residual cholesteatoma in the MESNA group, while there was one in the non-MESNA group.

There are certain limitations to our study. One of the limitations is that limited number of cases were included in this study. Follow-up period of operated patients which was limited to a few years is another limitation. Besides hearing results could not be analyzed in the study because some of the patients were lost to follow-up and followup hearing tests could not be performed.

\section{CONCLUSION}

Our results indicate that mastoid obliteration using autogenous conchal/tragal cartilage is helpful in improving the outcomes of CWD mastoidectomy in patients with COM or cholesteatoma. During obliteration, care must be given to the anterior epitympanic region, which can be retracted.

\section{REFERENCES}

1. Palva T. Surgical treatment of chronic middle ear disease. II. Canal wall up and canal wall down procedures. Acta Otolaryngol. 1987;104:487-94. [CrossRef]

2. Abramson M. Open or closed tympanomastoidectomy for cholesteatoma in children. Am J Otol. 1985;6:167-9.

3. Beales PH. The problem of the mastoid segment after tympanoplasty. J Laryngol Otol. 1959;73:527-31. [CrossRef]

4. Males AG, Gray RF. Mastoid misery: quantifying the distress in a radical cavity. Clin Otolaryngol Allied Sci. 1991;16:12-4. [CrossRef]

5. Mosher HP. A method of filling the excavated mastoid with a flap from the back of the auricle. Laryngoscope. 1911;21:1158-63. [CrossRef]

6. Palva T. Cholesteatoma surgery today. Clin Otolaryngol Allied Sci. 1993;18:245-2. [CrossRef]

7. Hung T, Leung N, van Hasselt CA, Liu KC, Tong M. Longterm outcome of the Hong Kong vascularized, pedicled temporalis fascia flap in reconstruction of mastoid cavity. Laryngoscope. 2007;117:1403-7. [CrossRef]

8. Kaur N, Sharma DK, Singh J. Comparative Evaluation of Mastoid Cavity Obliteration by Vascularised Temporalis Myofascial Flap and Deep Temporal Fascial-Periosteal Flap in Canal Wall Down Mastoidectomy. J Clin Diagn
Res. 2016;10:MC08-11. [CrossRef]

9. Olson KL, Manolidis S. The pedicled superficial temporalis fascia flap: a new method for reconstruction in otologic surgery. Otolaryngol Head Neck Surg. 2002;126:538-7. [CrossRef]

10. Kahramanyol M, Ozunlu A, Pabuscu Y. Fascioperiosteal flap and neo-osteogenesis in radical mastoidectomy: long-term results. Ear Nose Throat J. 2000;79:524-6. [CrossRef]

11. Jo SY, Eom TH, Yang HC, Cho YB, Jang CH. Comparison of obliteration materials used for revision canal walldown mastoidectomy with mastoid obliteration. In Vivo. 2014;28:1207-12.

12. Lee HJ, Chao JR, Yeon YK, et al. Canal reconstruction and mastoid obliteration using floating cartilages and musculoperiosteal flaps. Laryngoscope. 2017;127:1153-60. [CrossRef]

13. Ghiasi S. Mastoid cavity obliteration with combined palva flapand bone pâté. Iran J Otorhinolaryngol. 2015;27:23-8.

14. Alves RD, Cabral Junior F, Fonseca AC, Bento RF. Mastoid Obliteration with Autologous Bone in Mastoidectomy Canal Wall Down Surgery: a Literature Overview. Int Arch Otorhinolaryngol. 2016;20:76-83. [CrossRef]

15. Shohet JA, de Jong AL. The management of pediatric cholesteatoma. Otolaryngol Clin North Am. 2002;35:84151. [CrossRef]

16. Cho SW1, Cho YB, Cho HH. Mastoid obliteration with silicone blocks after canal wall down mastoidectomy. Clin Exp Otorhinolaryngol. 2012;5:23-7. [CrossRef]

17. Kim BG, Kim HJ, Lee SJ, Lee E, Lee SA, Lee JD. Outcomes of Modified Canal Wall Down Mastoidectomy and Mastoid Obliteration Using Autologous Materials. Clin Exp Otorhinolaryngol. 2019;12:360-6. [CrossRef]

18. Black B. Mastoidectomy elimination. Laryngoscope. 1995;105(12 Pt 2 Suppl 76):1-3. [CrossRef]

19. Lee WS, Choi JY, Song MH, Son EJ, Jung SH, Kim SH. Mastoid and epitympanic obliteration in canal wall up mastoidectomy for prevention of retraction pocket. Otol Neurotol. 2005;26:1107-11. [CrossRef]

20. Rosenblunt B, Ahlvin RC, Carr CD. Silicone implants in the mastoid portion of the temporal bone. Ann Otol Rhino Laryngol. 1966;75:889-92. [CrossRef]

21. Shea JJ Jr, Malenbaum BT, Moretz WH Jr. Reconstruction of the posterior canal wall with Proplast. Otolaryngol Head Neck Surg. 1984;92:329-33. [CrossRef]

22. Renard JL, Felten D, Béquet D. Post-otoneurosurgery aluminium encephalopathy. Lancet. 1994;344:63-4. [CrossRef]

23. Reck R, Störkel S, Meyer A. Bioactive glass-ceramics in middle ear surgery. An 8-year review. Ann N Y Acad Sci. 1988;523:100-6. [CrossRef]

24. Chhapola S, Matta I. Mastoid obliteration versus open cavity: a comparative study. Indian J Otolaryngol Head Neck Surg. 2014;66(Suppl 1):207-13. [CrossRef]

25. Beutner D, Helmstaedter V, Stumpf R, et al. Impact of partial mastoid obliteration on caloric vestibular function in canal wall down mastoidectomy. Otol Neurotol. 2010;31:1399-403. [CrossRef]

26. Kurien G, Greeff K, Gomaa N, Ho A. Mastoidectomy and mastoid obliteration with autologous bone graft: a quality of life study. J Otolaryngol Head Neck Surg. 2013;23;42-9. [CrossRef]

27. Dornhoffer JL, Smith J, Richter G, Boeckmann J. Impact on 
quality of life after mastoid obliteration. Laryngoscope. 2008;1 18:1427-32. [CrossRef]

28. Akkari M, Gabrillargues J, Saroul N, et al. Contribution of magnetic resonance imaging to the diagnosis of middle ear cholesteatoma: analysis of a series of 97 cases. Eur Ann Otorhinolaryngol Head Neck Dis. 2015;131:153-8. [CrossRef]

29. Vercruysse JP, De Foer B, Somers Th, Casselman J, Offeciers E. Magnetic resonance imaging of cholesteatoma: an update. B-ENT. 2009;5:233-40.

30. Ueda H, Nakashima T, Nakata S. Surgical strategy for cholesteatoma in children. Auris Nasus Larynx. 2001;28:125-9. [CrossRef]

31. Kuo CL, Lien CF, Shiao AS. Mastoid obliteration for pediatric suppurative cholesteatoma: long-term safety and sustained effectiveness after 30 years' experience with cartilage obliteration. Audiol Neurootol. 2014;19:35869. [CrossRef]

32. Ars B, Wuyts F, Van de Heyning P, Miled I, Bogers J, Van Marck E. Histomorphometric study of the normal middle ear mucosa. Preliminary results supporting the gas-exchange function in the postero-superior part of the middle ear cleft. Acta Otolaryngol. 1997;117:704-7. [CrossRef]

33. Kalcioglu MT, Cicek MT, Bayindir T, Ozdamar OI. Effectiveness of MESNA on the success of cholesteatoma surgery. Am J Otolaryngol. 2014;35:357-61. [CrossRef]

34. Vincenti V, Magnan J, Saccardi MS, Zini C. Chemically assisted dissection by means of mesna in cholesteatoma surgery. Otol Neurotol. 2014;35:1819-24. [CrossRef] 